\title{
Designing Bilingual Scenarios to Promote English Language Learning at a Public School in Monteria
}

\author{
Yanilis Romero $^{1,2}$ \& Milton Pájaro Manjarres ${ }^{1,2,3}$ \\ ${ }^{1}$ Institución Educativa Antonia Santos, Montería, Córdoba, Colombia \\ ${ }^{2}$ Universidad de Córdoba, Montería, Córdoba, Colombia \\ ${ }^{3}$ Universidad de Sucre, Sincelejo, Sucre, Colombia \\ Correspondence: Milton Pájaro Manjarres, Transversal 12, 1-11 Barrio Galilea, Montería, Córdoba, Colombia. \\ Tel: 57-3017-357-916. E-mail: miltonpama@gmail.com
}

Received: January 21, 2016

Accepted: March 1, 2016 Online Published: March 3, 2016

doi: $10.5539 /$ elt.v9n4p83

URL: http://dx.doi.org/10.5539/elt.v9n4p83

\begin{abstract}
This research study examines the assumptions of creating bilingual scenarios to promote English language learning for 384 students of ninth, tenth and eleventh grade of a public school in Monteria Colombia. An action research methodology was carried out in this study. The findings of this research suggested that the creation of bilingual scenarios within the school facilitated the promotion of English language learning because the students felt the need to use the target language in different contexts and situations and also because they felt that they were an important part of the teaching-learning process.
\end{abstract}

Keywords: bilingual scenarios, English learning, teachers' methodologies, integrative syllabi

\section{Introduction}

Teaching English to students in primary and high school has become a research issue due to the fact that the age of compulsory English education has started as a policy since 2007 for all public schools in Colombia.

According to Bialystok and Miller (1999) the idea of a critical period hypothesis takes place when learning a foreign language or acquiring a second language when children learn it easier than adult people because they are biologically more prepared. That is why, if a learner starts the study of a foreign language like English before that critical period, that student would build more proficiency when communicating. However, proficiency levels seem to depend on factors like: type of program and curriculum, numbers of hours spent in English class, exposure to the target language and contexts used for teaching (Rixon, 2000).

Regarding the factors stated above, it is important to think about how teachers, parents and the school itself, cooperate with the process of language learning outside the classroom since, once students leave the English class, the language they hear in the hallways, out on the sidewalks and stores is their native one. That is why, a proposal of designing bilingual scenarios in and out the classroom was created in Antonia Santos high school in Monteria Colombia. The main purpose was the promotion of English language learning and get an improvement of the students' results in the ICFES (Instituto Colombiano para el Fomento de la Educación Superior) national test. The idea with this proposal was to build up second language scenarios in which English could be seen and felt outside the classroom.

This study adopted the definition of bilingual Scenarios from Abelló, Ehlers, Quintana who claim that "By scenario is usually meant a particular physical place where an action, situation or representation takes place, and the various circumstances relating to certain people or events. In addition, bilingual often refers to an individual or group of individuals who routinely uses two different languages" (2010) (Translated by the authors).

The research question that guided this study was: To what extent bilingual scenarios increase students' learning opportunities in ninth, tenth and eleventh graders at Antonia Santos School in Monteria, Colombia?

A great deal of effort was made during two years (research time) in order to come up with language contexts in and out of the classroom, increasing in this way, the students' learning opportunities, due to the fact that learning is an active process in which students construct ideas about language by engaging themselves in it (Dewey, 1938). Jonassen (1999) cited in Bhattacharya (2002) supports this idea when he states that: "Meaningful learning 
requires knowledge to be constructed by the learner, not transmitted from the teacher to the student".

\section{Method}

\subsection{Research Question}

Taking into account the statement of the problem and the discussion of relevant related literature, the following research question was stated: To what extent bilingual scenarios increase students' learning opportunities in ninth, tenth and eleventh graders at Antonia Santos School in Monteria, Colombia?

\subsection{Type of Study}

This study emerged from observational processes carried out inside the classroom. That is why, it can be said that this is an action research project since the main aims were to observe, describe, analyze, and interpret the facts, characteristics, and variables affecting the language learning process of students and their low performance in the ICFES test. In this case, the research team was interested in carrying out a small-scale intervention at school in 9, 10 and 11 grade paying close attention to the effects or results of such intervention (Cohen \& Manion, 1994).

The process by which the research went through can be briefly described in two stages: the discovery stage and the intervention stage.

In the discovery stage some elicitation techniques were applied. Some of them include: a needs analysis comprised in two parts, a language proficiency test and a survey about the students' likes, dislikes, desires and feelings.

Observation rubrics were also used to analyze the language lessons systematically among colleagues. Besides that, surveys and interviews were applied to parents, coordinators and teachers of other subjects.

In the implementation stage, the information was gathered through journals written by both: students and teachers, and interviews conducted to parents and administrative stuff. It is also important to mention that some informal talks with the students as well as some unstructured questionnaires were applied to know the students' own point of view in regards to their learning process and progress.

\subsection{Participants}

The population involved in this study included 384 students of ninth, tenth and eleventh grade from Antonia Santos High School in Monteria, Colombia. All these students are Spanish native speakers, and their age ranges are between thirteen and seventeen years old. Regarding their English teaching background it is quite poor since what they know has been easily forgotten year after year. Most of these students come from low-income families and a great percentage of them live in the areas around the school.

Most of the students show interest in recreational activities and a good attitude towards new things. The whole target group has shown enthusiasm at the time of responding to any request done by the research team. The target population involved in this study was a significant amount of students as they were a third part of school population belonging to the upper levels in this school.

\subsection{Data Analysis}

The data analysis in this research study was carried out based on Grounded Theory. A grounded approach was used to analyze the information collected in order to establish categories, draw conclusions and suggest changes that may lead to get an improvement in both: English learning and the results of the ICFES National Test. Reflection nourished by observation, writing and interviewing, shed light on how effective this implementation was. The idea of using categories to analyze all the data collected was to reduce the amount of data to more manageable themes (Nunan \& Bailey, 2009).

The data collected was analyzed by categorizing the questions included in the different procedures, and also by carrying out quantitative analysis. Then, two kind of analysis took place. Firstly, a qualitative analysis was made taking into account the information shown by the data collection instruments used before the intervention and the application of the strategies used to promote language learning during the intervention stage. Secondly, quantitative methods were used to classify and evaluate the information collected in terms of students' attitudes towards the English Class, students' likes and interests, the methodology and the materials used to teach English and the Evaluation strategies used.

All the information presented in this part resulted from the actual application of the elicitation techniques proposed in the discovery stage. A careful analysis was made after gathering all the necessary information. This data was first assembled with the purpose of doing an initial examination and setting down researchers' own 
thoughts, ideas and impressions about the problem. Then, the information collected was coded into categories identifying common patterns among the instruments. Later, it was compared to determine which patterns were repeated and could be developed across the different data gathering techniques. In this phase of the analysis, the categories were classified in order of importance taking into account the research goals. The final step in this initial phase was the interpretation of particular patterns in each category which were made through descriptions that contained a summary of the students' likes and dislikes, school policies and national requirements.

\section{Discussion}

As it was previously stated, this research was carried out in two stages: the discovery stage and the intervention stage.

\subsection{Discovery Stage}

The following lines describe in more detail the categories found in the discovery stage:

\subsubsection{Teachers' Methodology}

Regarding this category, it is relevant to mention that according to the information observed and registered in the observation rubrics, a great amount of students in ninth, tenth and eleventh grade disliked their teachers' principle to teach them due to the fact that they kept a passive and receptive role during the lessons.

Furthermore, it was noticed that the teachers guided their teaching processes based on grammar rules and structured explanations. In other words, students were learning the usage of the English language rather than its use, which is in total disagreement with the document of the national standards in foreign languages written by the ministry of education in 2007 where it is stated that in the case of English the main objective is to develop the communicative competence which includes the pragmatic, the linguistic and the socio-linguistic competence, (cartilla de estandares en idiomas extranjeros, 2007).

Regarding the content to be taught and the activities used for teaching, they were not designed taking into account the students' interests or preferences. In fact, the teacher was the only one who could decide what to teach and how to do it. That is why, most of the activities were centered on the teacher and not on the students. In other words, the teacher was the focus of the teaching and learning process, which could be considered a mistake since it is widely known that an effective teaching process should be student-centered.

\subsubsection{Exposure to the Target Language}

English teachers in ninth, tenth and eleventh grade at Antonia Santos high school were not able to use English as the language of instruction because students complained about it most of the time. For this reason, teachers usually used the language just for mentioning some words, greeting the class and drilling some sounds. Unfortunately, this fact was remarkable because teachers made the decision of not using English in class anymore as it was seen during the observation stage. In contrast to this, some students reported in the needs analysis that they would like to talk and sing in the target language but as they were just taught grammar rules they felt quite handicapped to perform such a goal. As one of the children stated in one of the questions in the need analysis (Student from11-A 2009) "a mi me gustaría cantar y hablar Inglés pero no se puede en las clases porque no utilizamos el inglés y además me da pena" ("I would like to sing and talk in English but it is not possible in class because we do not use English and besides that I am shy"). There was clear evidence that learners were not encouraged to hear the language and as a consequence they were not confident enough to feel that they could learn the language after being exposed to it. However, it was not possible to take for granted that all learners were reluctant to hear or use the English language during the classes which could also be seen during the discovery stage.

In addition, most of the students claimed that they preferred to work in small groups, while the teachers mostly made them to work individually. This strategy did not allow learners to gain confidence with themselves and with the rest of the classmates when interacting in oral activities. Maybe through group work, the students could have more opportunities for peer correction during lessons. It could be observed that the decisions of some English teachers about the methodology to be used for instruction, differed from the kind of procedure that students seemed to feel best working with.

\subsubsection{Students' Attitude towards English Language Learning}

It was noticed that students' motivation towards English learning was relatively low. During the observation process it was possible to see that most of the students did not take an active role or participated in the class. The reason for this could be that the activities developed in class were boring as well as the methodology used to carry out the classes. Even though, two of the teachers observed manifested to have certain interest in promoting 
motivation in the classroom, the reality observed in the classes was that the activities developed in the classroom did not match with that purpose. It worths to mention that in the Institutional Education Project or PEI (Proyecto Educativo Institucional) it is stated that the classes of any subject should be enjoyable for the learner, and the learning environment should be adequate for the development and fulfillment of the objectives proposed in each subject.

During the discovery stage, the factors mentioned previously (have fun when learning and good environment) were not consistent with what is taking place in the language teaching processes developed with ninth, tenth, and eleventh graders at Antonia Santos High School.

\subsection{Intervention Stage}

The results of the discovery stage confirmed and reinforced the idea that Antonia Santos High School needed a well-organized teaching structure which could lead students to gain confidence and feel free to use the English language inside and outside the classroom as well as a defined syllabus which helped to improve students' language learning and the development of the communicative competence. This intervention stage was thought to be applied during two academic years while the school calendar takes place; in other words, the strategies proposed to impact this research study were executed at least twice a year. After their application, the information collected was carefully analyzed to evaluate its potential and the effect they had in the target population. The development of the intervention stage carried out to cover and improve the existing needs of the students and the teaching-learning process in general could be described as follows.

\subsubsection{Designing Bilingual Scenarios for Language Learning}

The research group decided to create a proposal which could maximize the students' learning opportunities at all times without the teacher, inside and outside the classroom. All this responded to the idea that neither second language learning nor second language teaching are individual endeavors.

In addition, young learner's success is commonly attributed to their widely observed tendency to acquire language without overtly analyzing the forms of language. In fact, language acquisition lays on the learners' capacity to grasp meaning from their environment. Barry McLaughlin refers to this as automatic processing with peripheral attention to language forms (McLaughlin, 1990). In other words, in order to manage the complexity of language, both: adults and children sooner or later must move away from processing the language little by little and acquire a complete form of language since words, affixes, and grammar rules are only on the periphery attention and learning does not take place until enough comprehensible input is given not only to teachers in the classroom but also to the environment itself.

As mentioned before, creating bilingual scenarios and contexts to have the students constantly involved in the learning process is a purposeful strategy whose benefits could be endless and priceless for those learners who were going to encounter meaningful ways to work on and practice the language outside the classroom.

The following lines will give an account of the bilingual contexts created during the intervention research to promote English language learning in and outside the classroom

\subsubsection{Bilingual Settings in the Classroom with the English Teacher}

\subsubsection{Integrative Syllabi}

To help teachers in the design of bilingual contexts within the classroom it was necessary to give shape and life to the school curricula due to the fact that making meaning for learners or facilitating the process whereby learners make their own meaning is not an isolated process where only teachers take part. The first step was to restructure the school syllabi and outline the framework to be adopted by the teachers to clearly know, what, when, how and why to teach. As it is known, a course without a syllabus does not have operational foundations. For this proposal, we adopted the concept of Robinson (1991) and Brumfit (1984) in which syllabus is considered a plan of work about what is going to be taught (grammar, vocabulary, functions, topics, strategies...). Both authors, consider learners and teachers as the major participants in the syllabus implementation. For the former, the syllabus represents a plan and organization of lessons, for the latter, it is a guideline and context for the content of a class.

The aforementioned change took into account the participation of students' likes and dislikes, the teachers' ideas and reflections, the coordinators' point of view and guidelines from the national ministry of education regarding foreign languages and the English standards. An integrative syllabus approach was chosen, considering the needs of the school community to enhance students' language learning and to get an improvement on the students' scores in the ICFES test. The aim was to focus on the four skills without leaving aside any of them, as it is 
commonly seen in many language programs in secondary schools in Monteria (Romero 2004).

Besides that, the scope and sequence of this syllabus is expressed in terms of competences as they are closely interrelated rather than treated in separate segments, as Brown (1994, p.219) states: "curriculum designers are taking more of a whole language approach whereby reading is treated as one of two or more interrelated skills".

Another positive aspect about integrative skill syllabus is that it offers students the opportunity to diversify their efforts in more meaningful tasks. That is why Brown (2000) claims that such integration can utilize a strong, principled approach to the separate, unique characteristic of each skill.

The format adopted was the following:

Table 1. Format for the integrative skills syllabus

STANDARDS

Production and

Comprehension

\section{COMPETENCES}

(Basic, citizenship, and labor)
PERFORMANCE

INDICATORS
THEMES AND

GRAMMAR POINTS

\subsubsection{Useful Phrases Used in the Classroom for Instruction and Clarification}

A set of 10 useful phrases were chosen in order to get students use them within the classroom while having English classes. According to Vygotsky (1978 cited in Lantolf and Apple, 1994) during the development process, a child learns first from his or her surrounding environment through social interactions with others; taking into account this premise, this strategy was introduced to the students as a resource for them to communicate with the teacher in the target language, expressing what they needed. For instance if they needed to go to the restroom they could say "may I go to the restroom?" or if they had the need to go over a simple explanation, they could say "could you repeat please?". This set of expressions were firstly mimed, drilled and written, then practiced with the purpose getting the students to use them in the classroom. Among the phrases were questions such as: could you speak slowly, please?, May I drink some water, please? And so forth. As the expressions became more popular, the expression were painted by the students on the wall, to keep them in mind (see Appendix A).

The purpose behind getting the students use these phrases was to get them familiarized with the language and start building some confidence around the possible communication between the student and the teacher.

Then, the same set of phrases and ten commands were given to the school community, at the beginning of the academic year, to promote English language use not only in the English classes but also in other sessions. From the janitor of the school up to the school director, a piece a paper full of the aforementioned expressions, including the meaning and a possible pronunciation transcript. These guides as they were called, were handed the first week of the academic year in assembly when the researchers could not only explain the purpose of the project but also drilled and clarify doubts about the pronunciation of words such as restroom instead of bathroom.

In both cases: students and the school community, English started to be used in and out classroom. Students and teachers began to greet each other saying hi, or hello! In addition, the teachers from other subjects like chemistry used these command in his class. He liked to say open your notebooks, and the reaction of students was positive as they saw other people in the school trying to do what they were required to. The science teacher manifested in informal conversation that he wanted to receive English classes or take a course because he could speak more in English with the learners.

\subsubsection{Visits to the Cinema}

As in Monteria there are few opportunities to put into practice English, the research team proposed the idea of taking students into the cinema where most movies are presented in English. After the school's principal approval, two visits to the cinema during each year were carried out by each of the groups of ninth, tenth and eleventh (see Appendix B). The movie theaters were the perfect place to fulfill a dual objective: to promote English language learning and to offer students a space different from school where they could have fun.

Before the movie was chosen, students were taught how a movie was divided, for example: introduction, plot, resolution and ending. Lexis related to movies (soundtrack, scenes, characters, and stuntman) was studied and 
reinforced before visiting the multiplex. Another resource used to implement this strategy was the design of a movie chart given to the students before going to the show. After watching the movie, the students were required to complete this chart in English. In this sense, students started to see the need of learning English and began little constructions of phrases using L2, which was a great advance for the research team because it was possible to see how motivated learners were to use the target language.

Taking the students out of the classroom to visit the mall where the cinema is, was something incredibly amazing for many reasons. First, students were really excited about being engaged to do something out of the classroom. Second, there were a great number of students whose experience at going to the cinema was the first and their happiness was clearly seen in their eyes. Having the chance to do something with their classmates out of the school was another positive factor that had an influence in the success of this activity.

To scaffold students' progress during the English classes, the teacher put them in pairs to build their own written production and later the teacher directed their attention to positive constructions and make corrections on their own written production.

\subsubsection{English Festival and Spelling Contest}

One of the main reasons why students wanted to learn English was to talk. However, within the school there were not enough opportunities for talking. For this reason, the research team created two scenarios out of the class where students could use what they knew. These two scenarios were: the English festival and the spelling contest. Both activities were established in the school calendar of the year. The English Festival was designed with the purpose of showing what students had learned during the English classes: a song, a rhyme, a short role play, a short reading, among other activities.

The objective of the English festival was to unfold students' performance and give importance to what they had previously done in the classes, make them feel they were part of the process and offer them a sense of achievement and motivate those students who were presenting and the ones who were part of the audience. One of the main outcomes during the English festival was to change the paradigm that in a public school children were not able to use English to communicate, it was interesting to see how impressed the teachers were after looking at the students' performance in these activities.

The Spelling Contest was a different scenario which had a learning aim. The main purpose of the spelling contest was to design a set of lexical items and use the alphabet to spell different words. The contest was designed as a competition where students from sixth and seventh grade were challenged to get a winner in category A. Eight and ninth graders did the same in category B, and tenth and eleventh graders did it in category C. Each of the categories had a winner, and the prize was meaningless in contrast to the excitement provoked by this language scenario among all the school community. In the first spelling contest, only students participated of this activity but after the second year, teachers became part of the contest as well. Both the English Festival and the spelling contest were celebrated one a year.

Once the research finished, the school academic council considered positive to include these two events in the students' academic life. Nowadays these scenarios including school trips to the cinema are institutionalized in Antonia Santos high school.

\subsubsection{International Exchanges}

A US non-profit organization was linked to this project and they sent during the two years of the implementation phase, two American English teachers to support the English language teaching and learning process that the research team carried out in the school. The two American teachers came for two weeks and were fully sponsored by the American government.

The scenario recreated in the classroom when having a native speaker in the English session gave a greater value to the learning of listening, as the English sounds reproduced by a Spanish native speaker is different from the ones who were born in an Anglo speaking country. Something similar happened with the students' speaking ability, which was fostered through the questions asked and answered from 9th, 10th, and 11th graders. It was possible to see how students attempted to use English to communicate basic ideas with these people, since pupils knew they did not speak Spanish.

These two teachers worked with the target population, a wide range of activities like: games and gap filling handouts. Furthermore, they drilled sounds with students like TH /ठ / Thank / $/$ / which do not exist in the Spanish language. These teachers co-taught with the teacher in charged and closely worked on the betterment of the class planning. 
In general terms it could be said that the impact the strategies from the intervention stage had on the students was positive. In terms of language learning, motivation was raised, which is a key and essential factor when learning a foreign language. And those fellows' impressions were really good as it can be seen in one of the teacher's blog after the visit: https://cuandoestuveencolombia.wordpress.com. The scenarios designed were the first step to foster the use of the English in and outside the classroom not only by learners but by the whole school community. Regarding the national ICFES test, the performance of eleventh graders considerably improved. From 2008 to 2010 the increase was notorious. In 2008 the average performance was 38.57. In contrast in 2009 and 2010 the results were 44.81 and 49.26 respectively.
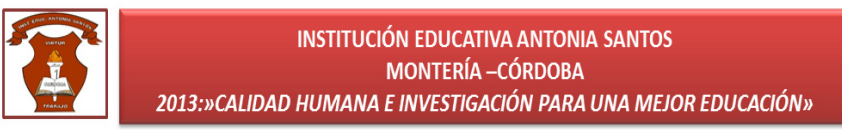

\begin{tabular}{|c|c|c|c|c|c|c|c|c|c|c|c|c|c|}
\hline \multicolumn{14}{|c|}{ RESULTADOS HISTORLCOSSABER 11 ANTONAASANTOS } \\
\hline Periodo & Geocopila & Quírice & Fisica & Eilobgy? & Hisionla & Filossila & $\frac{\text { Matemailic }}{\underline{a}}$ & Lenglate & $\frac{\text { Ciercas }}{\text { Sociases }}$ & nogles & Categoria & Evaluados & $\frac{\text { Yode }}{\text { Evaluados }}$ \\
\hline 2012 & & 8 & 8 & 8 & & 8 & 8 & 8 & 8 & 8 & SPERIOR & 98 & $.100 \%$ \\
\hline $2011^{\text {th }}$ & & 8 & 8 & 8 & & 8 & 8 & 7 & 8 & 8 & SPFEROR & 12.2 & $.100 \%$ \\
\hline $2010^{\circ}$ & & 9 & 8 & 8 & & 8 & 8 & 7 & 8 & 8 & SPEERIOR & 120 & $(98,47 \%)$ \\
\hline $2009^{9}$ & & 7 & 7 & 6 & & 7 & 6 & 6 & 8 & 7 & MEDIO & 133 & \\
\hline $2008^{\circ}$ & & 1 & 7 & i & & 7 & 6 & 6 & 7 & $j$ & MEDIO & 120 & \\
\hline $2007^{\circ}$ & & 7 & 8 & 7 & & 6 & 7 & 7 & 6 & 6 & MEDIO & 124 & \\
\hline 2003 & & 6 & 7 & 7 & & 8 & 6 & 8 & 7 & & MEDIO & 96 & \\
\hline 2005 & 5 & 6 & 7 & 7 & 6 & 7 & 6 & 6 & & & EANO & 61 & \\
\hline 2004 & 8 & 5 & 8 & 7 & 8 & 7 & 5 & 9 & & & MEDIO & 71 & \\
\hline 2003 & 5 & 5 & 7 & 6 & 6 & 6 & 5 & 7 & & & EANOO & NA & \\
\hline 2002 & 5 & 6 & 6 & $i$ & $j$ & 6 & 5 & 7 & & & EANOO & 76 & \\
\hline 2001 & 4 & 6 & 6 & 6 & 5 & 5 & 4 & 6 & & & WEERIOR & 64 & \\
\hline
\end{tabular}

Figure 1. ICFES Results between 2008 and 2012. Taken from: www.ifcesintervactivo.gov.co

\section{Conclusions}

This study allowed us to find out if it was possible to promote English Learning taking into consideration the students' needs and wants. Learners were able to perceive English not only as a subject of the curriculum but also as a mean to communicate ideas, sing, dance, etc. They could use the language to interact with other people in classes not just with the teacher. After the intervention stage, the main conclusion drawn from the study was that English language learning could be promoted if students' felt the necessity to use the target language in a given situation, in addition students' motivation could raise if they were an important part of the teaching-learning process.

Furthermore, it is relevant to take into consideration the fact that the target population was a third part of the whole school community and the results were notorious. A great number of students evidenced being influenced positively by the scenarios proposed and those who did not show evidences were surely exposed to the English language in different ways. The importance of recreating scenarios like the English festival and the spelling contest was to make learners feel the main reason why these began to take place in the school.

Another conclusion that could be drawn after the design and implementation of bilingual scenarios within the school was that during the two years of implementation, a significant improvement in the results of the ICFES national test was evident, a crucial fact to promote equality and more possibilities for students to thrive in life.

This research is a piece of contribution to improve the quality of English language teaching and learning which was born from the belief that learning a foreign language is not a privilege for students at private institutions but a paradigm that can be dismissed. This study is open to be adapted and implemented in other teaching settings worldwide.

\section{References}

Abelló , E. Q. (eds). (2010). Escenarios bilingües:El contacto de lenguas en el individuo y la sociedad. Bern, 
Berlin, Bruxelles, Frankfurt am Main. New York: Oxford.

Bhattacharya, M. (2002). Creating a Meaningful Learning Environment Using ICT. CDTL Brief. Retrieved January 16th, 2016, from: http://www.cdtl.nus.edu.sg/brief/v5n3/sec3.htm

Bialystok, E., \& Miller, B. (1999). The problem of age in second-language acquisition: influences from language, structure, and task. Bilingualism: Language and Cognition, 2(2), 127-145. http://dx.doi.org/10.1017/S1366728999000231

Brown, H.D. (1994). Principles of Language Learning and Teaching. New Jersey: Prentice Hall Regents.

Brown, H. D. (2000). Teaching by Principles. USA: Pearson ESL.

Brumfit, C. (1984). Function and structure of a state school syllabus for learners of second or foreign langauges with heterogeneous needs.

Cohen, L., \& Manion, L. (1994). Research methods in Education (4th ed.) London: Routledge.

Dewey, J. (1938). Experience and education. New York, NY: Kappa Delta Pi.

Lantolf, J. P., \& Appel, G. (eds.) (1994). Vygotskian approaches to second language research. Norwood: Ablex Publishing Corporation.

Mclaughlin, B. (1990). "Conscious" versus "Unconscious" Learning. TESOL Quarterly, 24, 617-634. http://dx.doi.org/10.2307/3587111

Ministerio de Educación Nacional, MEN. (2006). Estandares básicos de competencias en Lenguas Extranjeras: Inglés Formar en lenguas extranjeras jel reto! Lo que necesitamos saber y saber hacer. Revolución Educativa. Colombia Aprende. Bogotá.

Nunan, D., \& Bailey, K. (2009). Exploring Second Language Classroom Research: A comprehensive guide. Boston: Heinle/CENGAGE learning.

Rixon, S. (2000). Optimum age or optimum conditions? Issues related to the teaching of languages to primary age children. Retrieved from https://www.academia.edu/11435939/Optimum_Age_or_Optimum_Conditions

Robinson, P. (1991). ESP today. New York: Prentice Hall.

Romero, Y. (2009). Promoting language learning through a thematic vocabulary-based syllabus in different grades. Latin American Journal of Content \& Language Integrated Learning, 2(1), 38-45. http://dx.doi.org/10.5294/lacli1.2009.2.1.6

\section{Appendices}

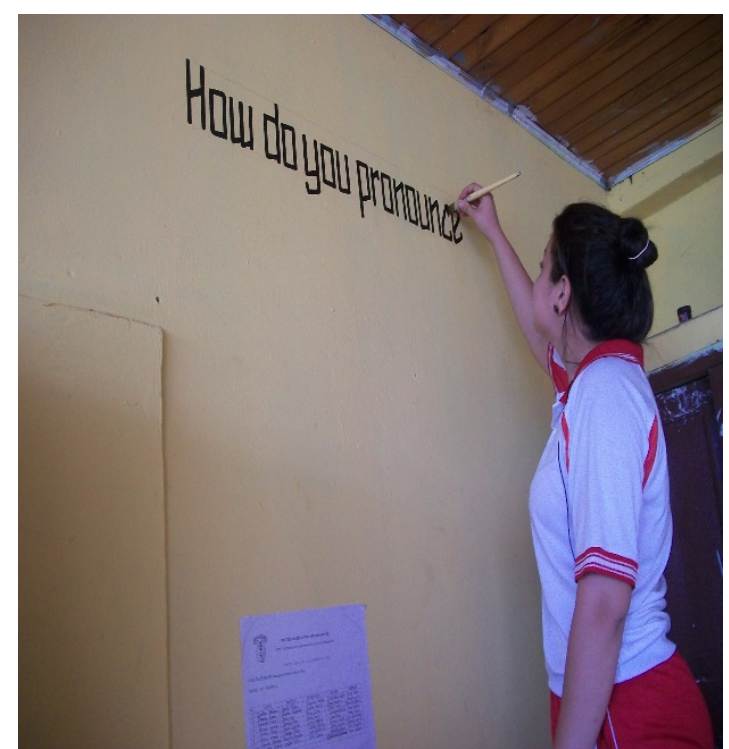

Appendix A

Student writing useful expressions on the wall

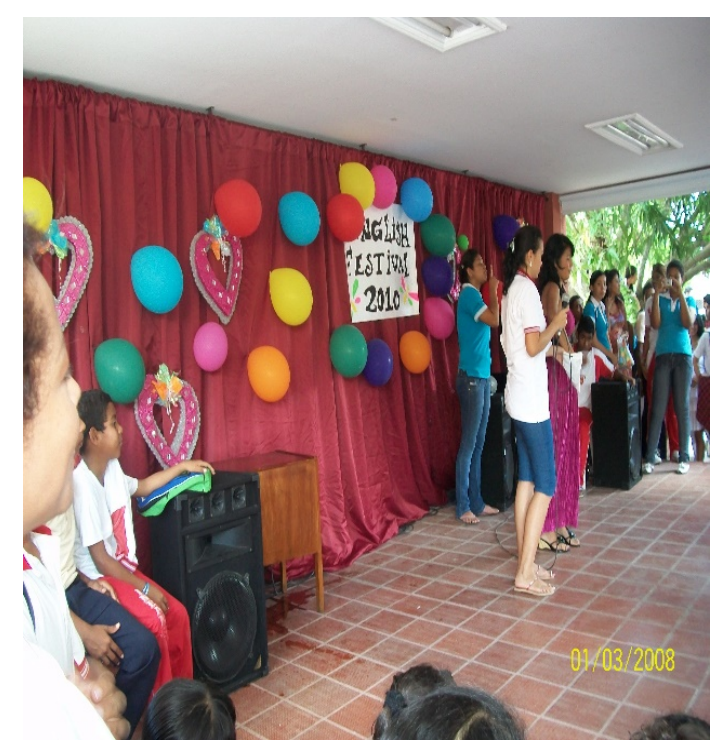

Appendix B

Students participating in the English Festival 


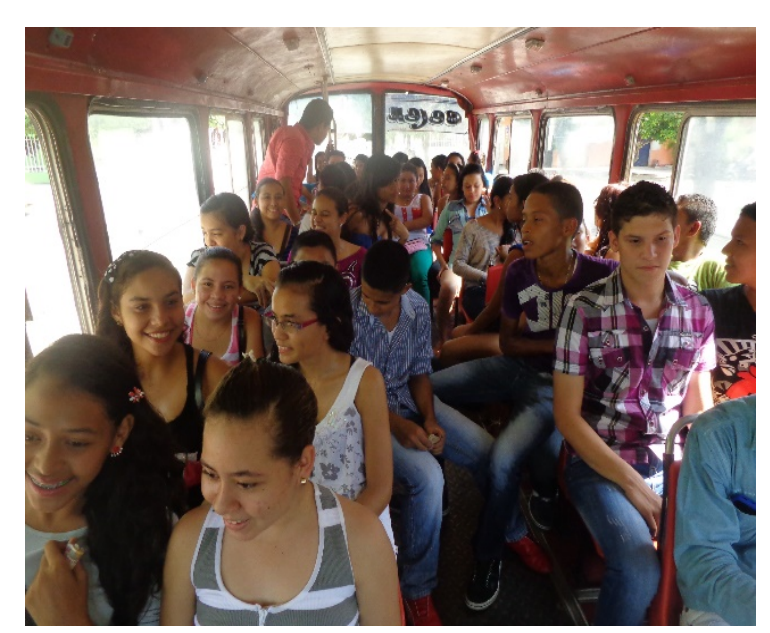

Appendix $\mathrm{C}$

Students going to the cinema

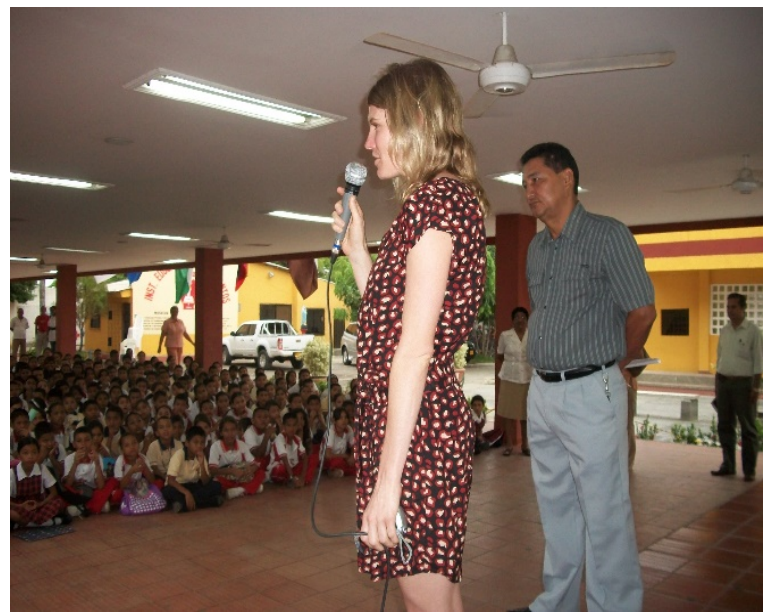

Appendix D

International teacher visiting antonia santos for two weeks

\section{Copyrights}

Copyright for this article is retained by the author(s), with first publication rights granted to the journal.

This is an open-access article distributed under the terms and conditions of the Creative Commons Attribution license (http://creativecommons.org/licenses/by/3.0/). 